Article

\title{
Investigating the Impacts of the COVID-19 Lockdown on Trace Gases Using Ground-Based MAX-DOAS Observations in Nanjing, China
}

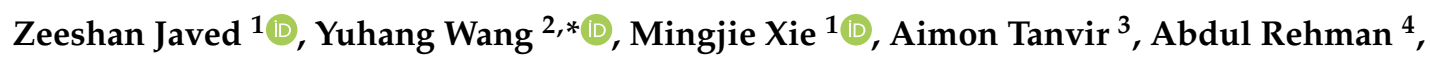 \\ Xiangguang Ji ${ }^{5,6}$, Chengzhi Xing ${ }^{6}$, Awais Shakoor ${ }^{7}$ and Cheng Liu ${ }^{6,8,9,10}$
}

1 Collaborative Innovation Center of Atmospheric Environment and Equipment Technology, Jiangsu Key Laboratory of Atmospheric Environment Monitoring and Pollution Control, School of Environmental Science and Engineering, Nanjing University of Information Science and Technology, Nanjing 210044, China; zeeshan@mail.ustc.edu.cn (Z.J.); mingjiexie@nuist.edu.cn (M.X.)

2 School of Earth and Atmospheric Sciences, Georgia Institute of Technology, Atlanta, GA 30332, USA

3 Department of Environmental Science \& Engineering, Fudan University, Shanghai 200433, China; 19110740045@fudan.edu.cn

4 CAS-Key Laboratory of Crust-Mantle Materials and the Environments, School of Earth and Space Sciences, University of Science and Technology of China, Hefei 230026, China; abdulrehman008@mail.ustc.edu.cn

5 School of Environmental Science and Optoelectronic Technology, University of Science and Technology of China, Hefei 230026, China; xgij2017@mail.ustc.edu.cn

6 Key Lab of Environmental Optics \& Technology, Anhui Institute of Optics and Fine Mechanics, Chinese Academy of Sciences, Hefei 230031, China; xingcz00@mail.ustc.edu.cn (C.X.); chliu81@ustc.edu.cn (C.L.)

7 Department of Environment and Soil Sciences, University of Lleida, Avinguda Alcalde Rovira Roure 191, 25198 Lleida, Spain; awais.shakoor@udl.cat

8 Center for Excellence in Regional Atmospheric Environment, Institute of Urban Environment, Chinese Academy of Sciences, Xiamen 361021, China

9 Department of Precision Machinery and Precision Instrumentation, University of Science and Technology of China, Hefei 230026, China

10 Anhui Province Key Laboratory of Polar Environment and Global Change, University of Science and Technology of China, Hefei 230026, China

* Correspondence: ywang@eas.gatech.edu

Received: 10 October 2020; Accepted: 26 November 2020; Published: 1 December 2020

check for updates

\begin{abstract}
The spread of the COVID-19 pandemic and consequent lockdowns all over the world have had various impacts on atmospheric quality. This study aimed to investigate the impact of the lockdown on the air quality of Nanjing, China. The off-axis measurements from state-of-the-art remote-sensing Multi-Axis Differential Optical Absorption Spectroscope (MAX-DOAS) were used to observe the trace gases, i.e., Formaldehyde $(\mathrm{HCHO})$, Nitrogen Dioxide $\left(\mathrm{NO}_{2}\right)$, and Sulfur Dioxide $\left(\mathrm{SO}_{2}\right)$, along with the in-situ time series of $\mathrm{NO}_{2}, \mathrm{SO}_{2}$ and Ozone $\left(\mathrm{O}_{3}\right)$. The total dataset covers the span of five months, from 1 December 2019, to 10 May 2020, which comprises of four phases, i.e., the pre lockdown phase (1 December 2019, to 23 January 2020), Phase-1 lockdown (24 January 2020, to 26 February 2020), Phase-2 lockdown (27 February 2020, to 31 March 2020), and post lockdown (1 April 2020, to 10 May 2020). The observed results clearly showed that the concentrations of selected pollutants were lower along with improved air quality during the lockdown periods (Phase- 1 and Phase-2) with only the exception of $\mathrm{O}_{3}$, which showed an increasing trend during lockdown. The study concluded that limited anthropogenic activities during the spring festival and lockdown phases improved air quality with a significant reduction of selected trace gases, i.e., $\mathrm{NO}_{2} 59 \%$, $\mathrm{HCHO} 38 \%$, and $\mathrm{SO}_{2} 33 \%$. We also compared our results with 2019 data for available gases. Our results imply that the air pollutants concentration reduction in 2019 during Phase- 2 was insignificant, which was due to the business as usual conditions after the Spring Festival (Phase-1) in 2019. In contrast, a significant
\end{abstract}


contamination reduction was observed during Phase-2 in 2020 with the enforcement of a Level-II response in lockdown conditions i.e., the easing of the lockdown situation in some sectors during a specific interval of time. The observed ratio of $\mathrm{HCHO}$ to $\mathrm{NO}_{2}$ showed that tropospheric ozone production involved Volatile Organic Compounds (VOC) limited scenarios.

Keywords: COVID-19; lockdown; remote sensing; $\mathrm{MAX}-\mathrm{DOAS} ; \mathrm{NO}_{2} ; \mathrm{SO}_{2} ; \mathrm{HCHO}$

\section{Introduction}

China has emerged as one of the world's largest economies with the fastest pace in industrialization and economic growth. The country has experienced a boom in its economy, starting from the 1980s. Currently, China is one of the largest economies of the world, at second place after the United States of America (USA). The country has a Gross Domestic Product (GDP) of 14.41 trillion US dollars as of 2019, while its GDP per capita has exceeded that of the USA [1]. However, these developments imply consequential costs. While the country has experienced rapid industrialization and motorization, large industrial sectors have emerged, especially in the southeastern part and have largely impacted the country's air quality. The geographic distribution of the pollutants and the emission strength however remain uncertain. In order to elucidate a clear picture of atmospheric profiles on a regional scale, observations from the downwind regions along with the source area are required. In the recent past, the Chinese Government has treated the environment as a priority and has taken substantial measures to enhance air quality [1,2]. Following these policy measures, positive developments have been shown in various studies on air quality, especially observed as reductions in Sulfur Dioxide $\left(\mathrm{SO}_{2}\right)$ and Nitrogen Dioxide $\left(\mathrm{NO}_{2}\right)$ columns as measured from satellites [1]. In many special case scenarios, substantial actions were taken in order to control atmospheric pollution including for Beijing Olympics (2008), Guangzhou Asian games (2010), Asian Pacific Economic Cooperation Conference (APEC, 2014), Youth Olympic Games in Nanjing (2014), and the China Victory Day Parade (2015). There has been a significant improvement in air quality during these events, and this has been reported in the literature [3-7]. Likewise, a change in atmospheric emission is observed during Spring Festival, also known as Chinese New Year, which is celebrated according to the traditional Chinese calendar or lunar calendar. This is the time of year when many people travel to their native homes and the local mobility of the city centers is reduced along with the closing of most offices, educational institutions, and industries, leading to a reduction in pollutant levels during this period, though the levels get back to normal soon after the festival is over [8-11].

At the end of 2019, a novel viral infection was reported in the city of Wuhan in China, which was identified as SARS-CoV-2 and the disease was named COVID-19. The disease produces mild symptoms of cold and flu in most patients but can lead to severe respiratory illness in many cases [12]. Despite the actions taken by the Chinese Government to limit the spread of the virus, it soon spread throughout the country, infecting thousands of people. In the next few weeks, the virus had spread across the world, affecting millions, while the World Health Organization (WHO) stated that the situation was a global health emergency and categorized it as a pandemic [13]. This outbreak followed strict prevention measures, leading to lockdowns in almost all the cities of China, the suspension of air transport, and restrictions on local mobility. Industries were shut down along with educational institutions and businesses. Public places were closed, and people were told to stay at home [14]. This kind of lockdown was first of its kind as an emergency response, which on the one hand, severely damaged the economy while, on the other hand, has led to positive impacts on air quality.

Recently, there have been some studies over various parts of the world, including China, Europe (Italy, Spain, France), and other parts of Asia (India and Kazakhstan), which explain the impact of the lockdown period on air quality and regional emissions. Significant reductions have been observed in the atmospheric concentration of $\mathrm{NO}_{2}$ while lesser, insignificant reductions have been 
found for $\mathrm{SO}_{2}$ in most cases. Ozone $\left(\mathrm{O}_{3}\right)$ concentration has significantly risen over all the regions in Volatile Organic Compounds (VOC) limited scenarios [15-23].

This study attempts to determine the impact that the lockdown to contain the spread of COVID-19 had on air quality over Nanjing, China. The off-axis measurements from ground-based observations using the Multi-Axis Differential Optical Absorption Spectroscope (MAX-DOAS) instrument for Formaldehyde ( $\mathrm{HCHO}), \mathrm{SO}_{2}$ and $\mathrm{NO}_{2}$ over Nanjing were analyzed to obtain column densities. The results were compared with in situ data for criteria pollutants, e.g., Ozone $\left(\mathrm{O}_{3}\right), \mathrm{SO}_{2}, \mathrm{NO}_{2}$, Particulate Matter less than $10 \mu \mathrm{m}\left(\mathrm{PM}_{10}\right)$, and Particulate Matter less than $2.5 \mu \mathrm{m}\left(\mathrm{PM}_{2.5}\right)$.

The main objective was to examine the effect of COVID-19 lockdown and hence reduced anthropogenic activity on daily mean concentration and diurnal cycle of pollutants. This study is organized as follows: Section 2 describes the observation site, instrument, and methodology. Based on this methodology, we developed a time series of pollutants, which is described in Sections 3.1 and 3.2. We also compared the effect of the Spring festival holidays of 2019 and 2020 in Section 3.3. The diurnal cycle of pollutants is discussed in Section 3.4. The ratio of $\mathrm{HCHO}$ to $\mathrm{NO}_{2}\left(\mathrm{R}_{\mathrm{FN}}\right)$ was examined to check if the $\mathrm{O}_{3}$ emissions are VOC limited or NOx limited, and discussion of this can be found in Section 3.5. Lastly, the effect of meteorological parameters is discussed in Section 3.6, followed by the discussion and conclusions sections.

\section{Materials and Methods}

\subsection{Instrument}

DOAS (Differential Optical Absorption Spectroscopy) serves as the basis for the MAX-DOAS (Multi-Axis DOAS) instrument that is used to observe various atmospheric trace gas species. MAX-DOAS contains a spectrometer (two Avaspec-UL2048L-USB2, UV: $300-405 \mathrm{~nm}$ and VIS: $407-540 \mathrm{~nm}$ ) with a resolution of about $0.6 \mathrm{~nm}$, a two-dimensional Charge-Coupled Device (CCD) detector (Sony ILX511, 2048 individual pixels), a telescope unit controlled by a stepping motor, multimode quartz glass fiber, and a controlling computer unit. Some of the external mechanical parts of this instrument are imported from Airyx Gmbh (Eppelheim, Germany) while the main system is designed and assembled by workers from "Key Lab of Environmental Optics \& Technology, Anhui Institute of Optics and Fine Mechanics". The field of view (FOV) and the elevation angle accuracy are better than $0.4^{\circ}$ and $0.2^{\circ}$. The temperature of the instrument is stabilized at around $20^{\circ} \mathrm{C}$. This MAX-DOAS system is used to collect scattered sunlight in order to make observations of the spectra at various viewing angles. A built-in processor automatically controls daily measurements.

\subsection{Observation Site}

The instrument was fixed on the top of the building in the Nanjing University of Information Science and Technology $\left(32.20^{\circ} \mathrm{N}, 118.72^{\circ} \mathrm{E}\right)$, as shown in Figure 1. The site is in Pukou District in the city of Nanjing. Pukou is one of the eleven districts of Nanjing, the capital of Jiangsu province. The district is separated from the main city by the Yangtze River. Nanjing has a population of more than 8.5 million. 


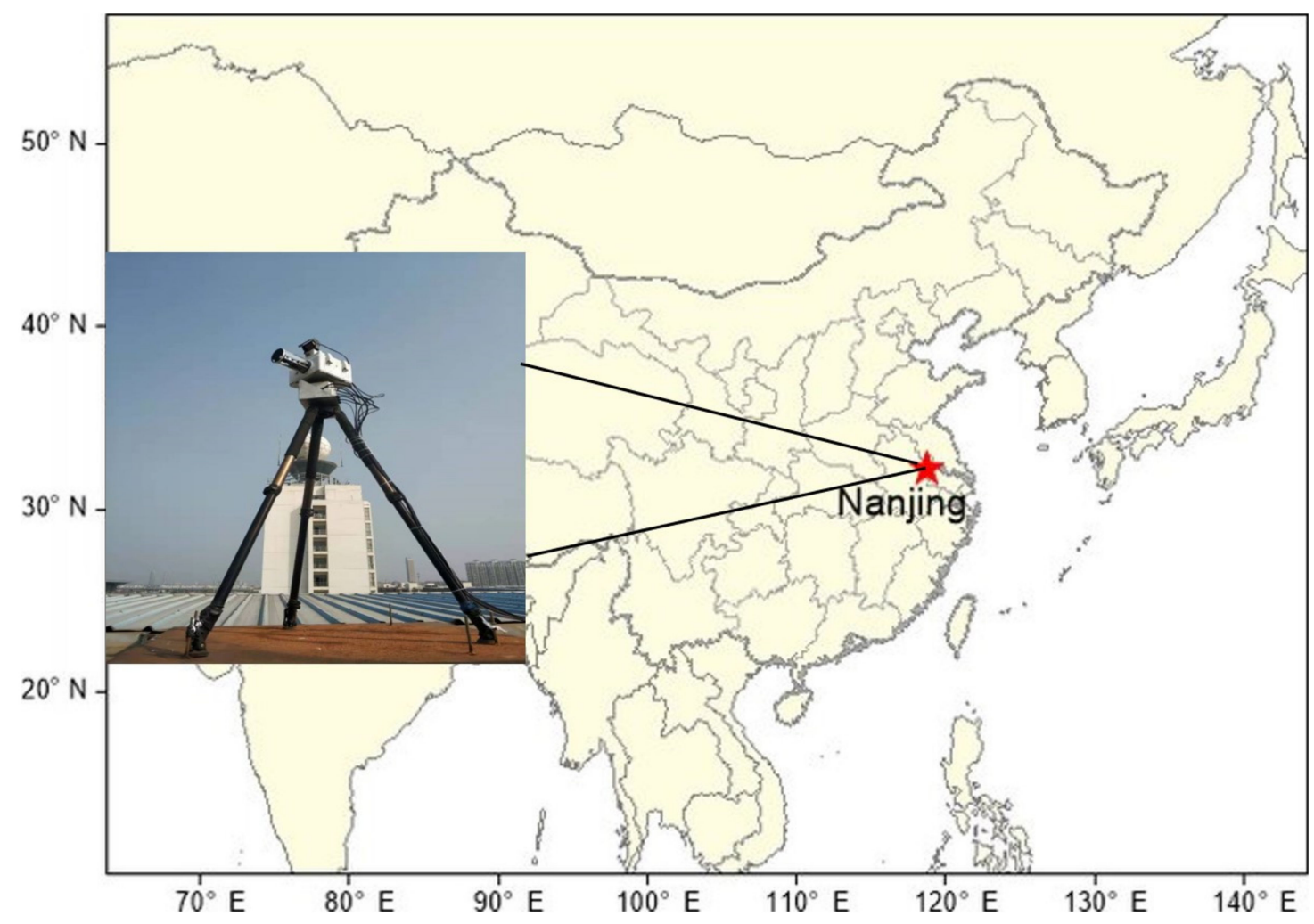

Figure 1. MAX-DOAS observation site at Nanjing University of Information Science and Technology, Pukou district, Nanjing.

\subsection{DOAS Analysis}

The MAX-DOAS instrument has the capacity to measure scattered sunlight at various altitudes, referred to as elevation viewing angles (EVA) in the atmosphere. This allows for the accurate column measurements for atmospheric trace gases. The instrument records spectra at various angles of elevation ranging from $1^{\circ}$ to $90^{\circ}$ and the azimuthal angle was kept constant $\left(145^{\circ}\right)$ with no obstruction in the field of view, while in other directions there was obstruction in the path of light from buildings and trees. In each measurement sequence, the zenith measurements were selected as a Frauenhofer reference spectrum, and they were subtracted by other off-zenith spectrum to calculate differential slant column densities (DSCDs). This method significantly minimizes the interference from stratospheric species to the tropospheric measurements [24]. The spectra were analyzed using the QDOAS software (version 3.2) developed by BIRA-IASB [25]. The best fitting wavelengths intervals and absorption cross-sections used in the DOAS fitting algorithm are described in Table 1. The high-resolution solar spectrum was used for wavelength calibration [26]. The measured spectra were corrected using offsets before analysis.

Fraunhofer reference spectrum was chosen at $90^{\circ}$, and it was used to fit the recorded spectra at diverse elevation angles in each series of the scanning. Differential slant column densities (DSCDs) were the outcome. Atmospheric scattering can impact the quality of data, and to avoid that, the data with a solar zenith angle greater than 75 and a root mean square (RMS) greater than 0.002 were filtered out. RMS represents the average instrument error for MAX-DOAS. Figure 2 shows a characteristic spectral fitting spectrum for DOAS at $30^{\circ}$ viewing angle, on 5 January 2020, at Nanjing station. 
Table 1. Detailed Settings for the spectral analysis of $\mathrm{NO}_{2}, \mathrm{HCHO}$, and $\mathrm{SO}_{2}$ using DOAS.

\begin{tabular}{llccc}
\hline \multirow{2}{*}{ Parameters } & \multicolumn{2}{c}{ Data Source } & \multicolumn{3}{c}{ Trace Gases } \\
\cline { 3 - 5 } & & $\mathbf{N O}_{2}$ & HCHO & SO $_{2}$ \\
\hline Wavelength (nm) & $298 \mathrm{~K},[27]$ & $337-370$ & $337-359$ & $312-326$ \\
$\mathrm{NO}_{2}$ & $220 \mathrm{~K},[27]$ & $\checkmark$ & $\checkmark$ & $\checkmark$ \\
$\mathrm{NO}_{2}$ & $298 \mathrm{~K},[27]$ & $\checkmark$ & $\mathrm{X}$ & $\mathrm{X}$ \\
$\mathrm{SO}_{2}$ & $297 \mathrm{~K},[28]$ & $\mathrm{X}$ & $\checkmark$ & $\checkmark$ \\
$\mathrm{HCHO}$ & $223 \mathrm{~K},[29]$ & $\checkmark$ & $\checkmark$ & $\checkmark$ \\
$\mathrm{O}_{3}$ & $243 \mathrm{~K},[29]$ & $\checkmark$ & $\checkmark$ & $\checkmark$ \\
$\mathrm{O}_{3}$ & $223 \mathrm{~K},[30]$ & $\checkmark$ & $\checkmark$ & $\checkmark$ \\
$\mathrm{BrO}$ & $293 \mathrm{~K},[31]$ & $\checkmark$ & $\checkmark$ & $\checkmark$ \\
$\mathrm{O}_{4}$ & Calculated with QDOAS & $\checkmark$ & $\checkmark$ & $\mathrm{X}$ \\
$\mathrm{Ring}$ & & 5 & 5 & $\checkmark$ \\
Polynomial degree & & $\checkmark$ & 5 \\
\hline
\end{tabular}
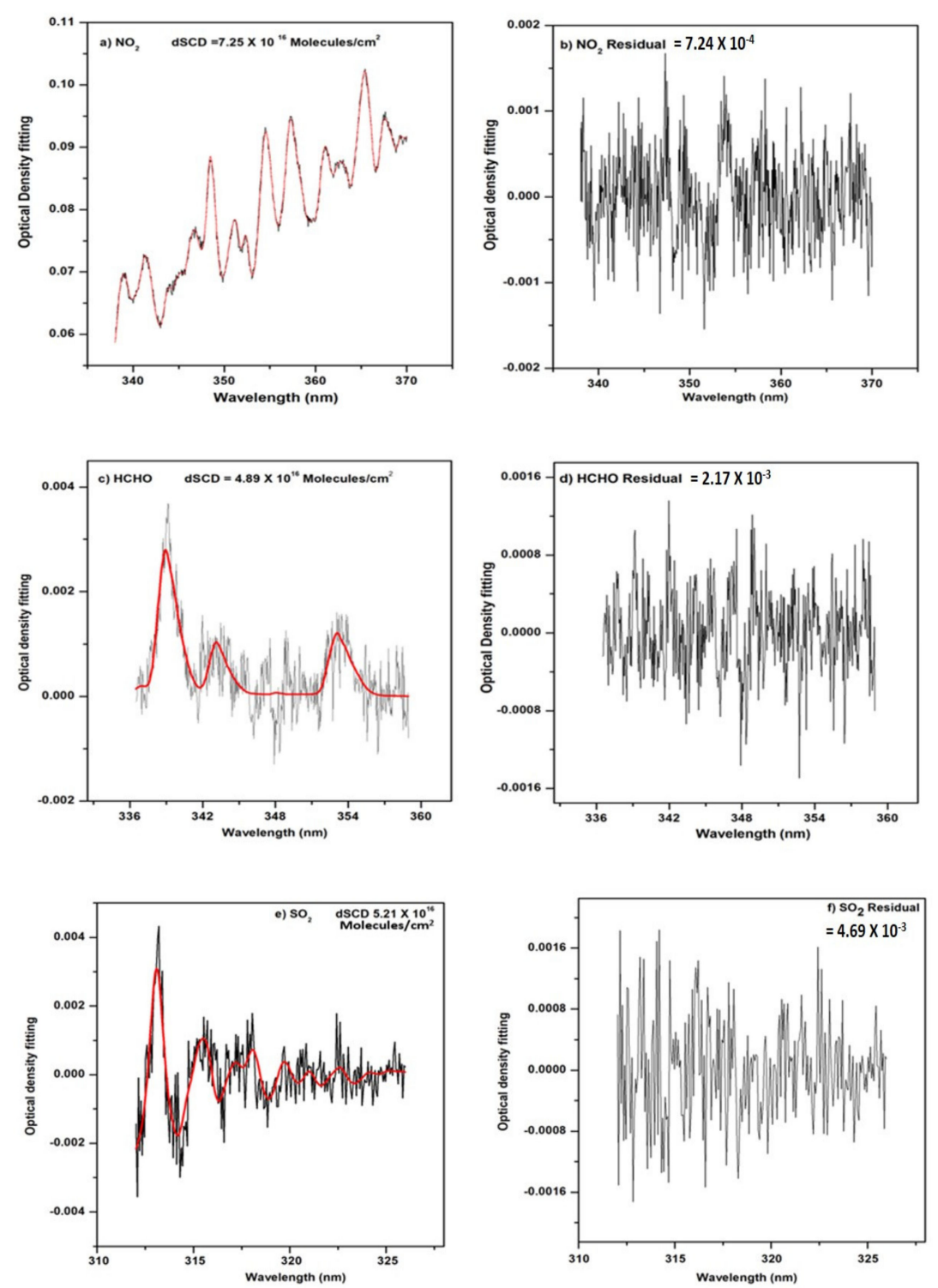

Figure 2. Fit for (a) $\mathrm{NO}_{2}$, (c) $\mathrm{HCHO}$, and (e) $\mathrm{SO}_{2}$ at $30^{\circ}$ elevation viewing angle. Residual for (b) $\mathrm{NO}_{2}$, (d) $\mathrm{HCHO}$, and (f) $\mathrm{SO}_{2}$ at $30^{\circ}$ elevation viewing angle. Fitted optical densities are represented by a red line while measured densities are denoted by the black line. The spectra were obtained on 5 January 2020, at Nanjing station. 
Vertical Column Density (VCDs) were calculated from dSCDs using differential air mass factors (dAMFs) [32,33]:

$$
\mathrm{VCD}_{\text {trop }}=\frac{\mathrm{dSCD}_{\alpha}}{\mathrm{dAMF}_{\alpha}}
$$

$\alpha$ denotes the angle used to make the consequent observation, whereas dAMF is given by the following equation:

$$
\begin{aligned}
\mathrm{dAMF}_{\alpha} & =\mathrm{AMF}_{\alpha}-\mathrm{AMF}_{90^{\circ}} \\
\mathrm{VCD}_{\text {trop }} & =\frac{\mathrm{dSCD}_{\alpha}}{\mathrm{AMF}_{\alpha}-\mathrm{AMF}_{90^{\circ}}} .
\end{aligned}
$$

The geometric approximation was used in order to calculate the AMF [34]:

$$
\mathrm{AMF}=\frac{1}{\sin _{\alpha}}
$$

Equation (3) now implies:

$$
\mathrm{VCD}_{\text {trop }}=\frac{\mathrm{dSCD}_{\alpha}}{1 / \sin _{\alpha}-1}
$$

Although this is a standard algorithm to get vertical column densities, some uncertainties are linked to this method for lower elevation viewing angles [35]. The tropospheric VCD calculation is based on an algorithm which uses two elevation angles: $30^{\circ}$ and $90^{\circ}$.

\subsection{Ancillary Data}

The data for in-situ measurements for $\mathrm{NO}_{2}, \mathrm{SO}_{2}, \mathrm{O}_{3}, \mathrm{PM}_{2.5}$, and $\mathrm{PM}_{10}$ was downloaded from https://www.aqistudy.cn/ (last accessed on 15 June 2020). The daily mean concentration data were used from 1 December 2019 to 10 May 2020.

\subsection{Meteorology Data}

The data for meteorological parameters of Nanjing was downloaded from NOAA's National Centers for Environmental Information (NCEI) (Available online: https:/www.ncdc.noaa.gov/, last accessed on 24 September 2020).

\section{Results}

The data spans over more than five months, from 1 December 2019, to 10 May 2020. The whole study period has been categorized into four distinct phases. The first phase covers pre-lockdown conditions starting from 1 December 2019 and ending on 23 January 2020. The second phase, termed as Phase-1 lockdown, begins from 24 January 2020, with the Level-I response to the epidemic control and ends on 26 February 2020. The third phase starts from 27 February and ends on 31 March 2020. This is categorized as a Phase-2 lockdown whereby Level-II response measures were adopted by the Government. Finally, the fourth phase is the post-lockdown period from 1 April to 10 May 2020. The data of the previous year i.e., from 1 December 2018, to 10 May 2019, was used for comparison. Although no lockdown happened in 2019, it was still categorized according to the characterization of 2020 data in order to make a comparison easier.

\subsection{MAX-DOAS Observations}

MAX-DOAS observations were done for $\mathrm{NO}_{2}, \mathrm{SO}_{2}$, and $\mathrm{HCHO}$ for this study. Daily average VCDs ranged from $7.58 \times 10^{15}$ molecules $/ \mathrm{cm}^{2}$ to $6.76 \times 10^{16}$ molecules $/ \mathrm{cm}^{2}$ with an average of $2.52 \times 10^{16}$ molecules $/ \mathrm{cm}^{2}$ for HCHO, $8.02 \times 10^{15}$ molecules $/ \mathrm{cm}^{2}$ to $1.82 \times 10^{17}$ molecules $/ \mathrm{cm}^{2}$ with an average of $6.66 \times 10^{16}$ molecules $/ \mathrm{cm}^{2}$ for $\mathrm{NO}_{2}$, and $9.28 \times 10^{15}$ molecules $/ \mathrm{cm}^{2}$ to $9.47 \times 10^{16}$ molecules $/ \mathrm{cm}^{2}$ with an average of $4.32 \times 10^{16}$ molecules $/ \mathrm{cm}^{2}$ for $\mathrm{SO}_{2}$ as generated from the MAX-DOAS observations. The DOAS fitting errors for $\mathrm{NO}_{2}, \mathrm{HCHO}$ and $\mathrm{SO}_{2}$ were less than $11 \%, 15 \%$, and $17 \%$, respectively. 
Figure 3 shows the time series of $\mathrm{VCD}$ of $\mathrm{NO}_{2}, \mathrm{HCHO}$, and $\mathrm{SO}_{2}$ for the study period. It is evident from the figure that the Phase-1 lockdown had a significant impact on the reduction of trace gases, especially $\mathrm{NO}_{2}$, while $\mathrm{HCHO}$ and $\mathrm{SO}_{2}$ depict a relatively lower level reduction as compared to $\mathrm{NO}_{2}$. Photochemistry and Meteorological parameters like wind speed, clouds cover, and temperature play a significant part in sinks and sources of several trace gases leading to seasonal variations. The pre-lockdown and post-lockdown phase occurred in different seasons. Therefore, we observed a difference in the concentration of trace gases between the pre lockdown and post lockdown phases. Figure 4 shows that $\mathrm{HCHO}$ has higher values in post lockdown and $\mathrm{NO}_{2}$ showed lower values in the post lockdown phase as compared to the pre lockdown phase.
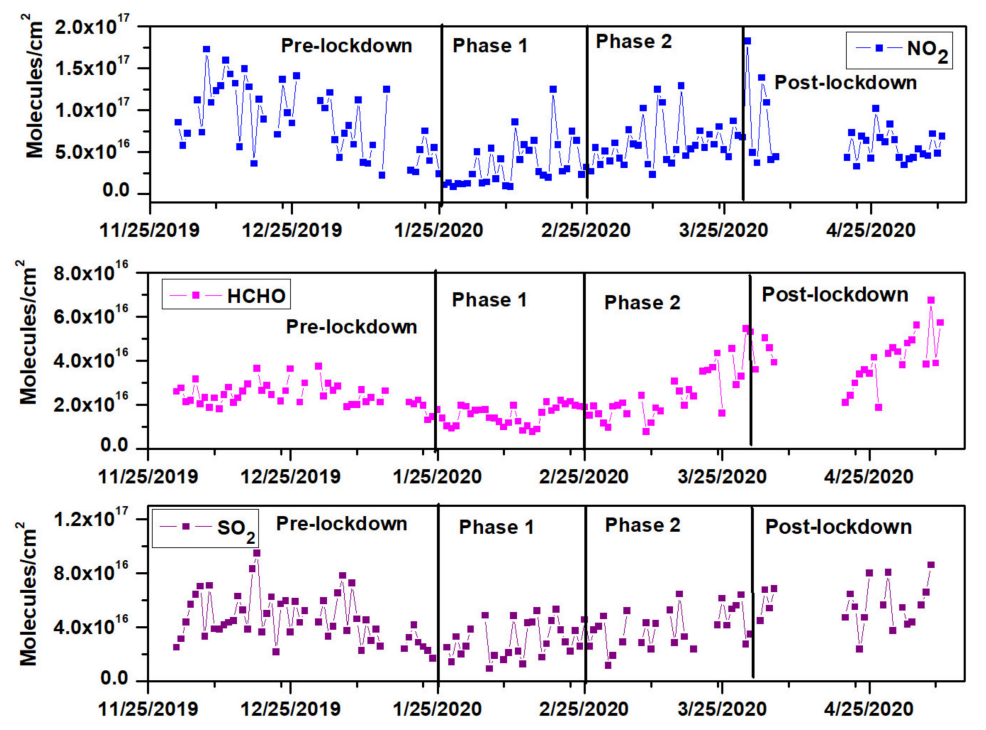

Figure 3. Time series for vertical column density of $\mathrm{NO}_{2}, \mathrm{HCHO}$, and $\mathrm{SO}_{2}$ at $30^{\circ}$ elevation viewing angle, obtained from MAX-DOAS observations for the study period over Nanjing. This has been categorized into four phases corresponding to pre-lockdown, lockdown (Phase-1 and Phase-2), and post-lockdown periods.
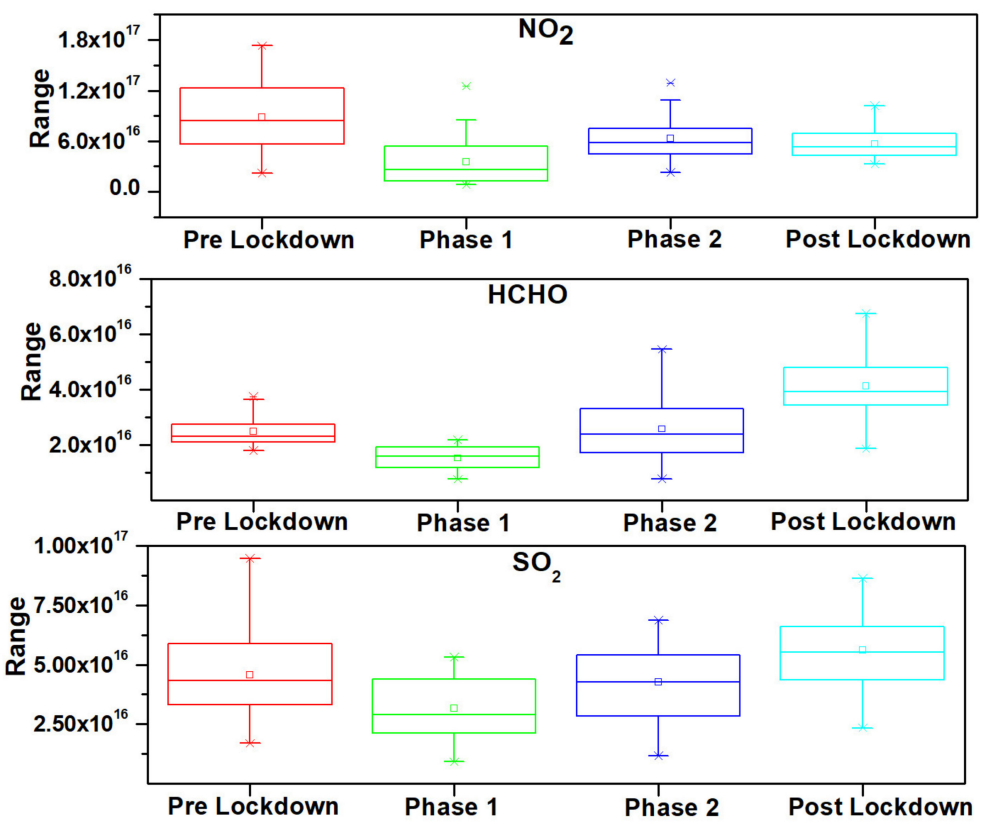

Figure 4. Boxplot for $\mathrm{NO}_{2}, \mathrm{HCHO}$, and $\mathrm{SO}_{2}$ VCDs obtained from MAX-DOAS observations for the study period over Nanjing. 


\subsection{In-Situ Measurements}

In-situ data was used in this study to generate time series for the criteria pollutants, for example $\mathrm{NO}_{2}, \mathrm{SO}_{2}$, and $\mathrm{O}_{3}$ during 2019 and 2020. Atmospheric concentration varied from 3-21 $\mu \mathrm{g} / \mathrm{m}^{3}$ with an average of $7.43 \mu \mathrm{g} / \mathrm{m}^{3}$ for $\mathrm{SO}_{2}, 13-84 \mu \mathrm{g} / \mathrm{m}^{3}$ with an average of $40.45 \mu \mathrm{g} / \mathrm{m}^{3}$ for $\mathrm{NO}_{2}$, and $9-189 \mu \mathrm{g} / \mathrm{m}^{3}$ with an average of $86.28 \mu \mathrm{g} / \mathrm{m}^{3}$ for $\mathrm{O}_{3}$ in 2020. During 2019, the concentration varied from $5-23 \mu \mathrm{g} / \mathrm{m}^{3}$ with an average of $11.09 \mu \mathrm{g} / \mathrm{m}^{3}$ for $\mathrm{SO}_{2}, 13-84 \mu \mathrm{g} / \mathrm{m}^{3}$ with an average of $46.18 \mu \mathrm{g} / \mathrm{m}^{3}$ for $\mathrm{NO}_{2}$, and $8-206 \mu \mathrm{g} / \mathrm{m}^{3}$ with an average of $77.02 \mu \mathrm{g} / \mathrm{m}^{3}$ for $\mathrm{O}_{3}$ The time series of in-situ measurements for various atmospheric species are depicted in Figure 5.

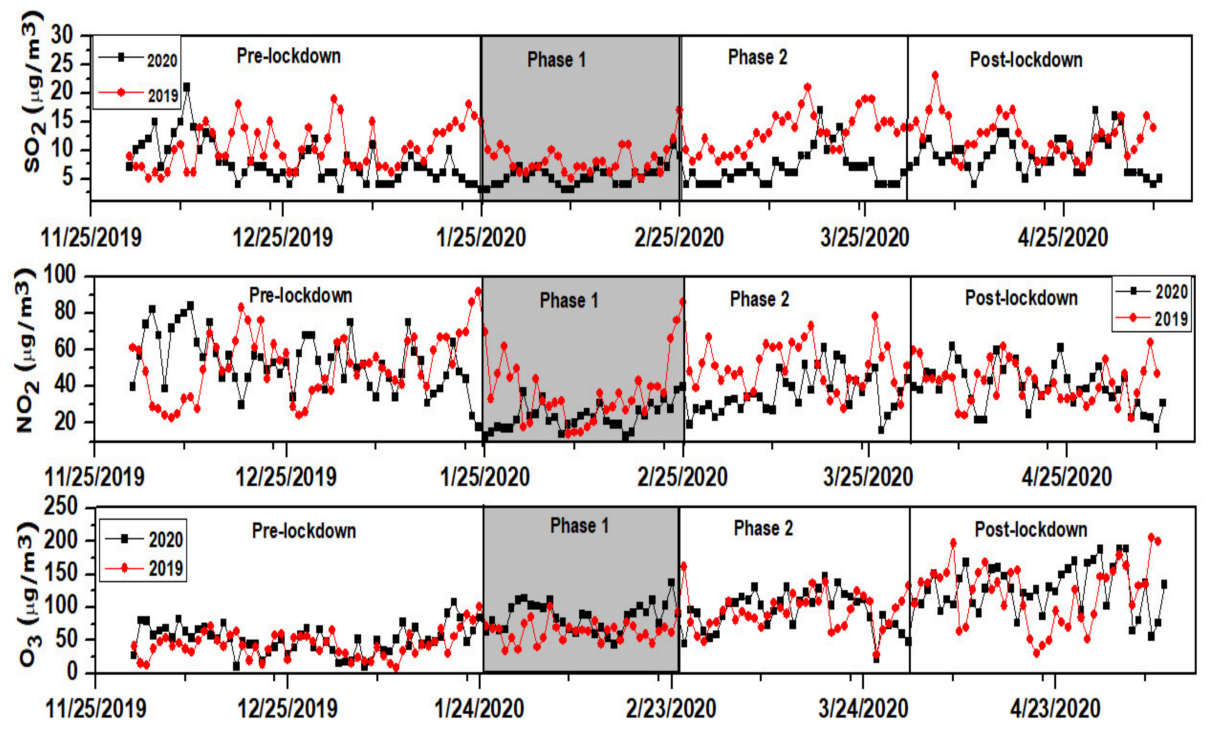

Figure 5. In-situ measurements of $\mathrm{SO}_{2}, \mathrm{NO}_{2}$, and $\mathrm{O}_{3}$ during 2019 and 2020.

In-situ measurements show a significant reduction in concentration of $\mathrm{NO}_{2}$ and $\mathrm{SO}_{2}$ during Phase-1 and Phase-2 of the lockdown in 2020. However, during 2019 improvement was only observed in Phase-1, which can be linked to the fact that the Chinese Spring Festival occurred in the first week of February in 2019, which will be discussed in detail in Section 3.3. There was no significant impact found of lockdown periods on $\mathrm{O}_{3}$ variation. It looks like the $\mathrm{O}_{3}$ concentration increased with an increase in the solar radiation in the late winter and spring. Similar trends have been reported in the recent studies over different parts of the world (Italy, Spain, France, India, and Kazakhstan) [15-23].

\subsection{COVID 19 Lockdown and Spring Festival}

The Spring Festival plays a key role in regulating air quality in China. As a two-week holiday with most offices and industries being closed, the festival often leads to a significant reduction in atmospheric air pollutants, as argued in the literature [16]. This year, the festival happened during the lockdown period Phase-1.

Therefore, we compared the reduction in emissions for Phase- 1 and Phase- 2 of the lockdown in 2020 with the same days in the previous year.

It is important to mention that MAX-DOAS data for 2019 was available for $\mathrm{NO}_{2}$ and $\mathrm{HCHO}$. MAX-DOAS data and in-situ data for 2019 were only used for comparative analysis in this section. A significant reduction in concentration of trace gases $\left(\mathrm{SO}_{2}, \mathrm{NO}_{2}\right.$, and $\left.\mathrm{HCHO}\right)$ was observed during the Spring Festival in 2019, while the level of these trace gases reduced further during 2020 due to coupling effect of COVID-19 lockdown and the Spring Festival. Figure 6 shows a comparison of concentrations of $\mathrm{HCHO}, \mathrm{SO}_{2}$, and $\mathrm{NO}_{2}$ for the four phases (defined above) in 2019 and 2020. 


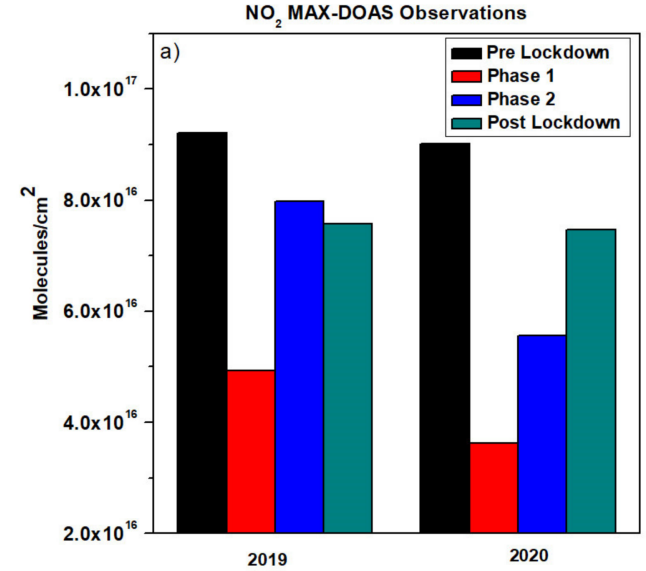

(a)

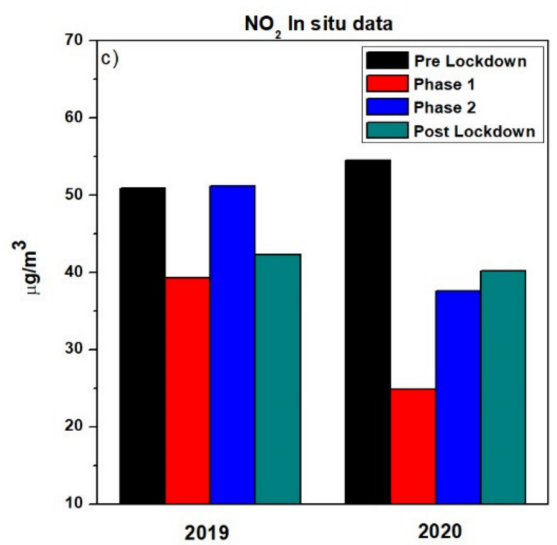

(c)

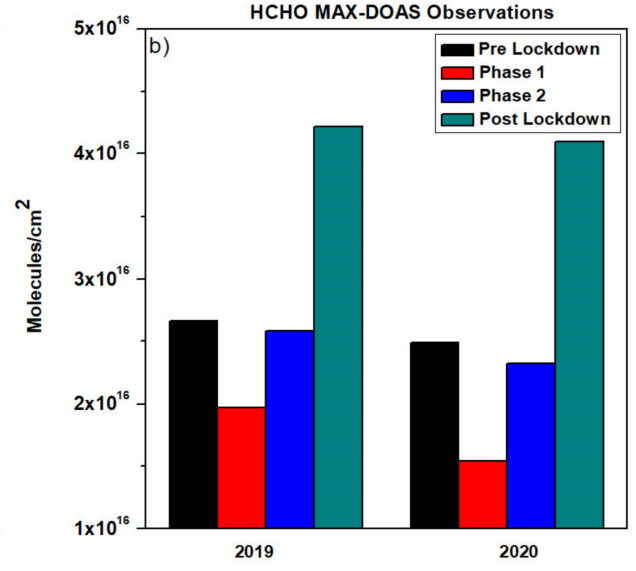

(b)

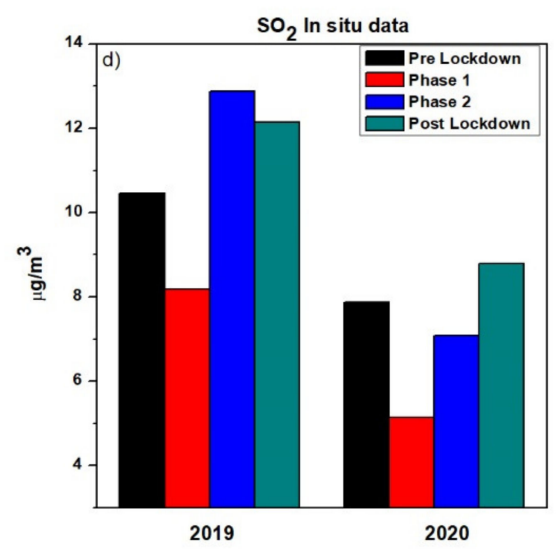

(d)

Figure 6. Comparison of (a) $\mathrm{NO}_{2}$ (MAX-DOAS), (b) $\mathrm{SO}_{2}$, (c) $\mathrm{NO}_{2}$ (In-situ) and (d) $\mathrm{HCHO}$ mean concentrations during different phases in 2019 and 2020.

Table 2 shows the changes in the mean concentration of different trace gases during Phase- 1 and Phase-2 of lockdown in 2019 and 2020.

Table 2. Shows a comparison of mean concentration changes during different phases in 2019 and 2020. (+ shows an increase in the concentration and - shows a reduction in the concentration).

\begin{tabular}{llccc}
\hline Trace Gas & Data Source & Year & Phase-1 & Phase-2 \\
\hline $\mathrm{NO}_{2}$ & MAX-DOAS & 2019 & $-46 \%$ & $-13 \%$ \\
& & 2020 & $-59 \%$ & $-26 \%$ \\
& In situ & 2019 & $-22 \%$ & $+1 \%$ \\
& & 2020 & $-56 \%$ & $-30 \%$ \\
\hline \multirow{2}{*}{$\mathrm{HCHO}$} & \multirow{2}{*}{ MAX-DOAS } & 2019 & $-26 \%$ & $-5 \%$ \\
& & 2020 & $-38 \%$ & $-8 \%$ \\
\hline $\mathrm{SO}_{2}$ & In situ & 2019 & $-23 \%$ & $+15 \%$ \\
& \multirow{2}{*}{ MAX-DOAS } & 2020 & $-35 \%$ & $-10 \%$ \\
& & 2020 & $-33 \%$ & $-13 \%$ \\
\hline
\end{tabular}




\subsection{Diurnal Variations}

The levels of atmospheric trace gases in the urban areas are closely linked to anthropogenic emissions. The diurnal variation is imperative towards knowing the atmospheric chemistry of trace gas species. Figure 7 shows diurnal variations of the trace gases for normal days compared to the lockdown period.
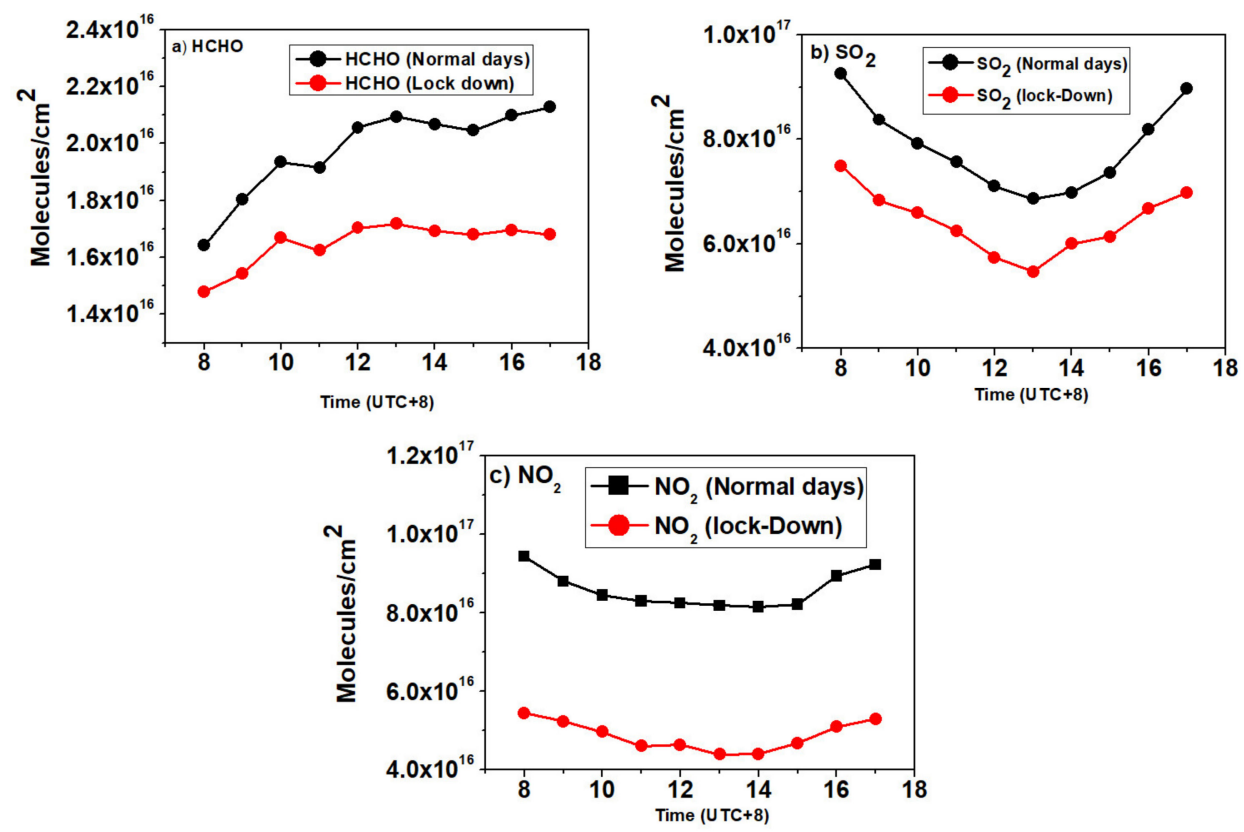

Figure 7. Diurnal variation in hourly mean VCDs of (a) $\mathrm{HCHO}$, (b) $\mathrm{SO}_{2}$, and (c) $\mathrm{NO}_{2}$ from MAX-DOAS averaged during normal days and the lockdown period.

The diurnal cycle for $\mathrm{HCHO}, \mathrm{SO}_{2}$, and $\mathrm{NO}_{2}$ has remained essentially the same during the lockdown period compared to the business as usual condition. $\mathrm{HCHO}$ showed an increase in concentration from morning to noon, with a small reduction during 10:00 to 11:00, rose again until noon (13:00) and a reduction occurred afterward followed by a rise in the evening. Several studies have reported similar trends for diurnal variation of $\mathrm{HCHO}[24,36] . \mathrm{SO}_{2}$ showed a steep decline from morning until noon and then increased in the afternoon. $\mathrm{NO}_{2}$ showed similar diurnal variation to that of $\mathrm{SO}_{2}$, but the reduction was less steep. The concentration began to accumulate for evening hours with heavy traffic loads $[37,38]$. For the lockdown period, the trend has remained the same despite the reduction in the overall concentration.

\section{5. $\mathrm{HCHO} / \mathrm{NO}_{2}$}

Nitrogen oxides and VOCs play a vital role in ozone formation by causing complex photochemical reactions [39]. Thus, the level of ozone can be controlled by dropping levels of VOCs or NOx, subject to which one is in excess. These conditions are normally referred to as VOC-limited and NOx-limited photochemical systems. The $\mathrm{HCHO}$ was used as a proxy for the reactivity of VOCs because $\mathrm{HCHO}$ is an oxidation product of different VOCs [40]. We used the ratio of $\mathrm{HCHO}$ to $\mathrm{NO}_{2}$ to study the sensitivity of $\mathrm{O}_{3}$ formation to precursor species of NOx and VOCs over Nanjing. Duncan et al. [41] described the linkage between the ratio of $\mathrm{HCHO} / \mathrm{NO}_{2}\left(\mathrm{R}_{\mathrm{FN}}\right)$ and $\mathrm{O}_{3}$ formation and suggested three regions: $\mathrm{R}_{\mathrm{FN}}<1$ for VOC-limited, $\mathrm{R}_{\mathrm{FN}}>2$ for NOx-limited, and $\mathrm{R}_{\mathrm{FN}}$ between 1 and 2 for transition regimes, where both (VOC-limit and NOx-limit) may reduce the ozone production. Here, the ratios of $\mathrm{HCHO}$ to $\mathrm{NO}_{2}$ were used to analyze the $\mathrm{O}_{3}$ sensitivity.

Figure 8 shows the ratio of $\mathrm{HCHO}$ and $\mathrm{NO}_{2}$ during our study period. Our results show that $\mathrm{R}_{\mathrm{FN}}$ lies mostly in the VOC-limited region. 


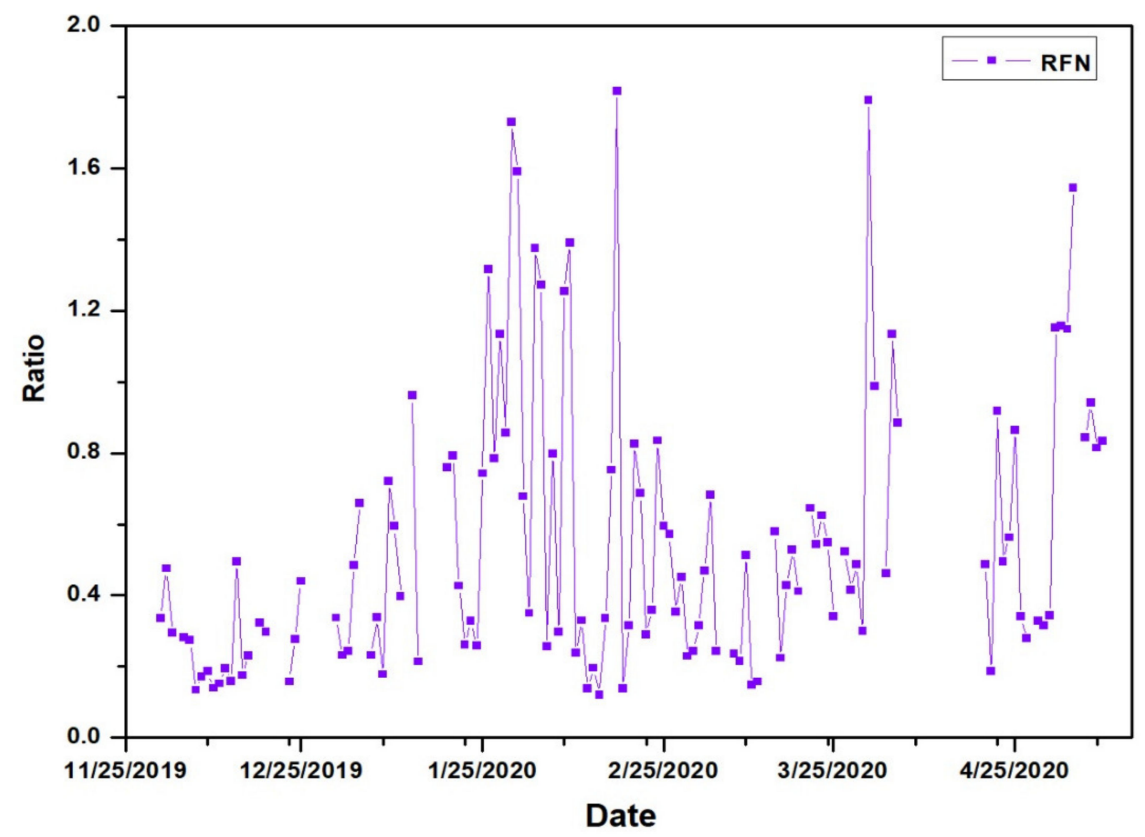

Figure 8. Daily averaged $\mathrm{HCHO} / \mathrm{NO}_{2}$ ratio at Nanjing.

\subsection{Impact of Meteorology}

Chemical behavior and residence time of the atmospheric pollutants are significantly impacted by the meteorological conditions over the locality. Substantial evidence has been found in literature regarding the effect of different meteorological parameters on trace gas and aerosol distribution [24,42]. The average meteorology data of Nanjing from January to March in 2020 was compared with the preceding year's data. There was no significant difference in meteorological conditions, as shown in Table 3.

Table 3. Comparison of meteorological parameters.

\begin{tabular}{lll}
\hline Parameters & 2017-2019 & $\mathbf{2 0 2 0}$ \\
\hline Avg Wind speed $(\mathrm{m} / \mathrm{s})$ & 2.7 & 2.6 \\
Avg Relative Humidity $(\%)$ & 74.8 & 78.3 \\
Avg Temperature $\left({ }^{\circ} \mathrm{C}\right)$ & 6.9 & 8.5 \\
\hline
\end{tabular}

Temperature and wind play an important role in concentration of trace gases. Therefore, temperature and windspeed were analyzed at a sub-seasonal time scale involved in our study. The temperature and wind speed are also analyzed according to the four categories (Pre-lockdown, Phase-1, Phase-2, Post-lockdown) of the study period. Figure 9 shows a boxplot for (a) wind speed and (b) temperature.

There was no significant difference in wind speed during different phases of our study period. Therefore, the role of wind speed in reduction of pollutant concentration during lockdown was insignificant. A study conducted in the Yangtze River Delta Region to investigate the effect of lockdowns on pollutants concentration also reported that there was no significant effect of wind speed and wind direction during the lockdown phase [14]. 

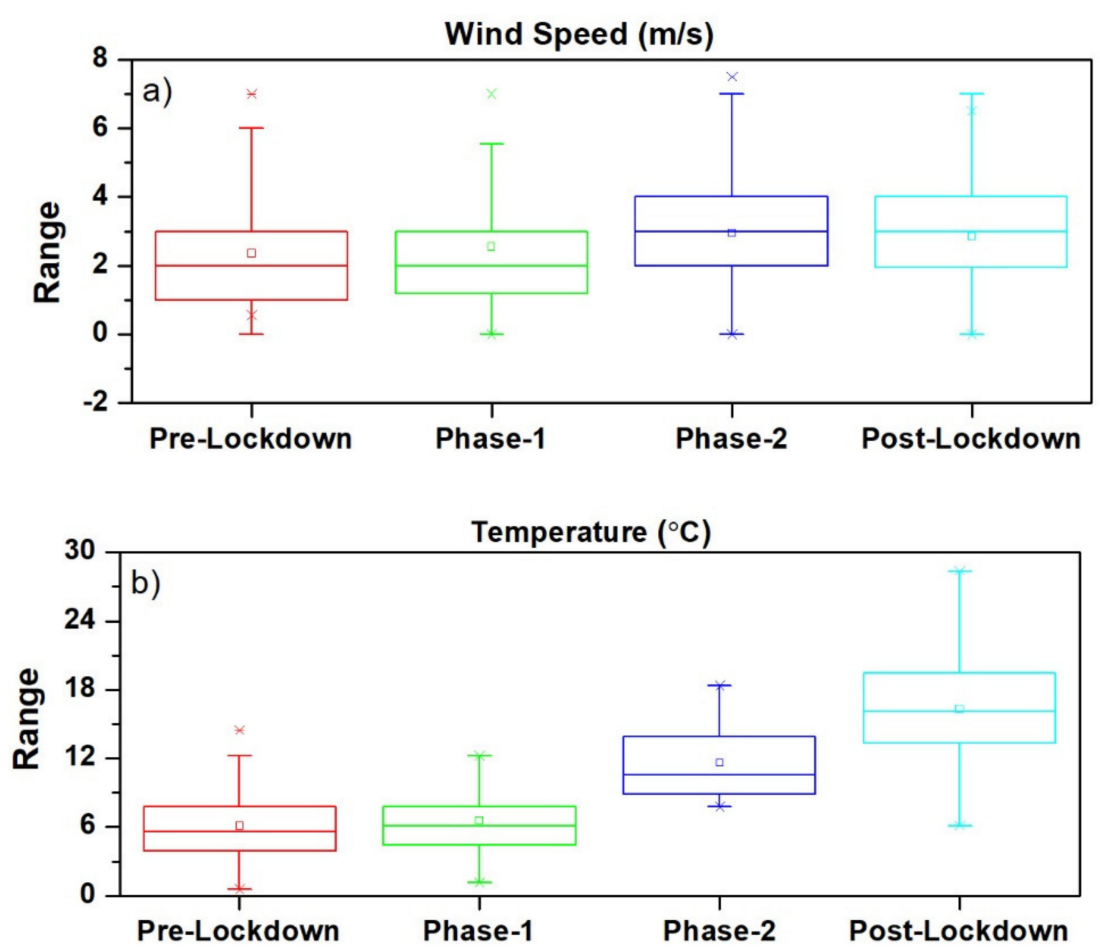

Figure 9. Boxplot for $(\mathbf{a})$ wind speed $(\mathrm{m} / \mathrm{s})$ and $(\mathbf{b})$ temperature $\left({ }^{\circ} \mathrm{C}\right)$.

The temperature data showed a growing trend from pre-lockdown to post-lockdown phase. Therefore, there must be some effect of temperature on the pollutants concentration. Different trace gases have different correlation with temperature. The temperature and $\mathrm{NO}_{2}$ anti correlate with each other, while $\mathrm{HCHO}$ and $\mathrm{O}_{3}$ have positive correlation with temperature [24,42]. Keeping in mind the aforementioned fact the $\mathrm{HCHO}$ concentration should increase when moving from pre-lockdown to post lockdown phase, our results showed that there was a significant reduction in the HCHO level during Phase- 1 and Phase-2, which could be related to the reduction in emissions from various sources due to the lockdown. However, $\mathrm{HCHO}$ levels were higher in the post lockdown phase as compared to the pre lockdown phase, which was mainly due to temperature as the pre-lockdown phase occurred in winter with an average temperature of around $5^{\circ} \mathrm{C}$ and the post-lockdown phase occurred in spring season with an average temperature of around $16^{\circ} \mathrm{C}$. The concentration of $\mathrm{NO}_{2}$ dropped significantly during Phase- 1 and Phase- 2 because of the combined effect of the temperature and lockdown. $\mathrm{The}^{\mathrm{NO}_{2}}$ level rose again in the post lockdown phase but still its concentration was reduced as compared to pre lockdown phase, which can be attributed to the fact that temperature was higher during the post lockdown phase which caused a reduction of $\mathrm{NO}_{2}$.

\section{Discussion}

The higher reduction in $\mathrm{NO}_{2}$ as compared to $\mathrm{HCHO}$ and $\mathrm{SO}_{2}$ was because $\mathrm{NO}_{2}$ is mainly produced from anthropogenic sources, hence the lockdown closure of industrial, economic, and transportation activities resulted in a lower load of $\mathrm{NO}_{2}$. The difference in the concentration of trace gases between the pre-lockdown and post-lockdown phases can be attributed to seasonal variations e.g., $\mathrm{HCHO}$ concentration started to increase in summer due to increased production from photo-oxidation of VOCs and $\mathrm{NO}_{2}$ started to decrease in summer due to a higher rate of photolysis [43].

The strong reduction in concentration of $\mathrm{NO}_{2}, \mathrm{SO}_{2}$, and $\mathrm{HCHO}$ during the Phase- 1 Lockdown was observed in 2020 as compared to 2019. According to data from the Ministry of Transport, there was almost a 50 percent decrease in the traffic load during the Spring Festival in 2020 as compared to 2019 (Available online: http://www.mot.gov.cn/ accessed on 22 June 2020). The data from the Jiangsu Energy Regulatory Office of the People's Republic of China showed a reduction by 19 percent in energy 
generation during lockdown Phase-1 in 2020 as compared to the same period in 2019 (Available online: http://jsb.nea.gov.cn/ accessed on 23 June 2020). The aforementioned facts led to a strong reduction in 2020 as compared to 2019.

The observed low concentration of $\mathrm{SO}_{2}$ and $\mathrm{NO}_{2}$ in the diurnal cycle at noon can be accredited to the increase in photo-oxidation and the photolysis rate of $\mathrm{NO}_{2}$ and $\mathrm{SO}_{2}$. Due to diminished rates of photolysis in late hours of the afternoon, $\mathrm{NO}_{2}$ and $\mathrm{SO}_{2}$ columns again started to rise [38]. The increase in the $\mathrm{HCHO}$ level at noon was due to the formation of $\mathrm{HCHO}$ from photo-oxidation of VOCs [24].

There was no significant impact of lockdown periods on $\mathrm{O}_{3}$ variation. It looks like $\mathrm{O}_{3}$ concentration increased with an increase in solar radiation in late winter and spring. The ratio of $\mathrm{HCHO}$ to $\mathrm{NO}_{2}$ was used to study the sensitivity of $\mathrm{O}_{3}$ formation to precursor species of NOx and VOCs. Our results show that $\mathrm{R}_{\mathrm{FN}}$ lies mostly in the VOC-limited region. The observed ratio of $\mathrm{HCHO}$ to $\mathrm{NO}_{2}$ showed that tropospheric ozone production was most likely VOCs limited, but further investigation is required.

There was no significant impact of meteorological parameters on trace gases during lockdown phase except for involving the surface temperature.

Different studies have been reported throughout the world to investigate the impact of COVID-19 lockdown on concentration of trace gases. Our results are consistent with other studies reporting that overall concentration of trace gases was reduced during lockdown periods [16-23].

\section{Conclusions}

Ground-based observations of $\mathrm{HCHO}, \mathrm{NO}_{2}$, and $\mathrm{SO}_{2}$ from the MAX-DOAS instrument over Nanjing were analyzed to obtain vertical column densities. The results were compared with in situ criteria pollutants, e.g., $\mathrm{O}_{3}, \mathrm{SO}_{2}$, and $\mathrm{NO}_{2}$. During the COVID-19 lockdown period, anthropogenic activities were reduced. The results showed a significant impact of the lockdown on $\mathrm{NO}_{2}$ emissions with a 59\% reduction, while less reductions were observed for $\mathrm{HCHO}$ and $\mathrm{SO}_{2}$ ( $38 \%$ and $33 \%$ respectively) during Phase-1. The Spring Festival also happened during Phase- 1 of the lockdown period, and emissions were usually low during the festival owing to the closing of offices and industries. Moreover, the study also provides a glance at the comparison of concentrations of the selected trace gases for the categorized phases in the COVID-19 pandemic situation in 2020 with the normal conditions in the previous year (2019). The results showed that the reduction was greater in the lockdown period in 2020 compared to under the normal conditions of 2019. The observed ratio of $\mathrm{HCHO}$ to $\mathrm{NO}_{2}$ showed that tropospheric ozone production was VOC limited. However, further investigation is required in this regard.

Author Contributions: Conceptualization, Z.J., Y.W., and C.L.; methodology, M.X., A.T, and Z.J.; software, X.J., C.X., and Z.J.; validation, X.J., Y.W., and A.R.; formal analysis, Z.J. and A.T.; investigation, Z.J; resources, Y.W. and M.X.; data curation, Z.J. and A.S.; writing—original draft preparation, Z.J., A.T., and A.R.; writing—review and editing, X.J., C.X., and C.L.; visualization, A.S.; supervision, C.L.; project administration, M.X. All authors have read and agreed to the published version of the manuscript.

Funding: This work was supported by the National Natural Science Foundation of China (NSFC, 41701551, 41605117, 41771291). Y.W. was supported by the National Science Foundation.

Acknowledgments: We are indebted to Lily, School of Environmental and Chemical Engineering, Shanghai University, for helping us in providing meteorology data for Nanjing from NOAA's National Centers for Environmental Information (NCEI).

Conflicts of Interest: The authors declare no conflict of interest.

\section{References}

1. Van Der A, R.J.; Mijling, B.; Ding, J.; Koukouli, M.E.; Liu, F.; Li, Q.; Mao, H.; Theys, N. Cleaning up the air: Effectiveness of air quality policy for $\mathrm{SO}_{2}$ and NOx emissions in China. Atmos. Chem. Phys. Discuss. 2017, 17, 1775-1789. [CrossRef] 
2. Sogacheva, L.; Rodriguez, E.; Kolmonen, P.; Virtanen, T.H.; Saponaro, G.; de Leeuw, G.; Georgoulias, A.K.; Alexandri, G.; Kourtidis, K.; van der A, R.J. Spatial and seasonal variations of aerosols over China from two decades of multi-satellite observations-Part 2: AOD time series for 1995-2017 combined from ATSR ADV and MODIS C6. 1 and AOD tendency estimations. Atmos. Chem. Phys. 2018, 18, 16631-16652. [CrossRef]

3. Chen, C.; Sun, Y.L.; Xu, W.Q.; Du, W.; Zhou, L.B.; Han, T.T.; Wang, Q.Q.; Fu, P.Q.; Wang, Z.F.; Gao, Z.Q. Characteristics and sources of submicron aerosols above the urban canopy (260 m) in Beijing, China, during the 2014 APEC summit. Atmos. Chem. Phys. 2015, 15, 12879-12895. [CrossRef]

4. Ding, J.; van der A, R.J.; Mijling, B.; Levelt, P.F.; Hao, N. NOx emission estimates during the 2014 Youth Olympic Games in Nanjing. Atmos. Chem. Phys. Discuss. 2015, 15, 6337-6372. [CrossRef]

5. Okuda, T.; Matsuura, S.; Yamaguchi, D.; Umemura, T.; Hanada, E.; Orihara, H.; Tanaka, S.; He, K.; Ma, Y.; Cheng, Y.; et al. The impact of the pollution control measures for the 2008 Beijing Olympic Games on the chemical composition of aerosols. Atmos. Environ. 2011, 45, 2789-2794. [CrossRef]

6. Xu, H.; Tao, J.; Ho, S.S.H.; Ho, K.F.; Cao, J.; Li, N.; Chow, J.C.; Wang, G.; Han, Y.; Zhang, R.; et al. Characteristics of fine particulate non-polar organic compounds in Guangzhou during the 16th Asian Games: Effectiveness of air pollution controls. Atmos. Environ. 2013, 76, 94-101. [CrossRef]

7. Zhao, J.; Du, W.; Zhang, Y.; Wang, Q.; Chen, C.; Xu, W.; Han, T.; Wang, Y.; Fu, P.; Wang, Z.; et al. Insights into aerosol chemistry during the 2015 China Victory Day parade: Results from simultaneous measurements at ground level and $260 \mathrm{~m}$ in Beijing. Atmos. Chem. Phys. Discuss. 2017, 17, 3215-3232. [CrossRef]

8. Feng, J.; Yu, H.; Su, X.; Liu, S.; Li, Y.; Pan, Y.; Sun, J.-H. Chemical composition and source apportionment of PM2.5 during Chinese Spring Festival at Xinxiang, a heavily polluted city in North China: Fireworks and health risks. Atmos. Res. 2016, 182, 176-188. [CrossRef]

9. Tang, M.; Ji, D.-S.; Gao, W.-K.; Yu, Z.-W.; Chen, K.; Cao, W. Characteristics of air quality in Tianjin during the Spring Festival period of 2015. Atmos. Ocean. Sci. Lett. 2016, 9, 15-21. [CrossRef]

10. Wang, C.; Huang, X.-F.; Zhu, Q.; Cao, L.-M.; Zhang, B.; He, L.-Y. Differentiating local and regional sources of Chinese urban air pollution based on the effect of the Spring Festival. Atmos. Chem. Phys. Discuss. 2017, 17, 9103-9114. [CrossRef]

11. Yao, L.; Wang, D.; Fu, Q.; Qiao, L.; Wang, H.; Li, L.; Sun, W.; Li, Q.; Wang, L.; Yang, X.; et al. The effects of firework regulation on air quality and public health during the Chinese Spring Festival from 2013 to 2017 in a Chinese megacity. Environ. Int. 2019, 126, 96-106. [CrossRef] [PubMed]

12. WHO. World Health Organization Novel Coronavirus (2019-nCoV). 2020. Available online: http://www.euro. who.int/en/health-topics/health-emergencies/novel-coronavirus-2019-ncov_old (accessed on 2 April 2020).

13. WHO (World Health Organization). WHO Director-General's Opening Remarks at the Media Briefing on COVID-19. 11 March 2020. Available online: https:/www.who.int/director-general/speeches/detail/ who-director-general-s-opening-remarks-at-the-media-briefing-on-covid-19---11-march-2020 (accessed on 4 July 2020).

14. Li, L.; Li, Q.; Huang, L.; Wang, Q.; Zhu, A.; Xu, J.; Liu, Z.; Li, H.; Shi, L.; Li, R.; et al. Air quality changes during the COVID-19 lockdown over the Yangtze River Delta Region: An insight into the impact of human activity pattern changes on air pollution variation. Sci. Total Environ. 2020, 732, 139282. [CrossRef] [PubMed]

15. Collivignarelli, M.C.; Abbà, A.; Bertanza, G.; Pedrazzani, R.; Ricciardi, P.; Miino, M.C. Lockdown for CoViD-2019 in Milan: What are the effects on air quality? Sci. Total Environ. 2020, 732, 139280. [CrossRef] [PubMed]

16. Dantas, G.; Siciliano, B.; França, B.B.; Da Silva, C.M.; Arbilla, G. The impact of COVID-19 partial lockdown on the air quality of the city of Rio de Janeiro, Brazil. Sci. Total Environ. 2020, 729, 139085. [CrossRef]

17. Fan, C.; Li, Y.; Guang, J.; Li, Z.; Elnashar, A.; Allam, M.; De Leeuw, G. The impact of the control measures during the COVID-19 outbreak on air pollution in China. Remote Sens. 2020, 12, 1613. [CrossRef]

18. Kerimray, A.; Baimatova, N.; Ibragimova, O.P.; Bukenov, B.; Kenessov, B.; Plotitsyn, P.; Karaca, F. Assessing air quality changes in large cities during COVID-19 lockdowns: The impacts of traffic-free urban conditions in Almaty, Kazakhstan. Sci. Total Environ. 2020, 730, 139179. [CrossRef]

19. Mahato, S.; Pal, S.; Ghosh, K.G. Effect of lockdown amid COVID-19 pandemic on air quality of the megacity Delhi, India. Sci. Total Environ. 2020, 730, 139086. [CrossRef]

20. Muhammad, S.; Long, X.; Salman, M. COVID-19 pandemic and environmental pollution: A blessing in disguise? Sci. Total Environ. 2020, 728, 138820. [CrossRef] 
21. Nakada, L.Y.K.; Urban, R.C. COVID-19 pandemic: Impacts on the air quality during the partial lockdown in São Paulo state, Brazil. Sci. Total Environ. 2020, 730, 139087. [CrossRef]

22. Sharma, S.; Zhang, M.; Gao, J.; Zhang, H.; Kota, S.H. Effect of restricted emissions during COVID-19 on air quality in India. Sci. Total Environ. 2020, 728, 138878. [CrossRef]

23. Tobías, A.; Carnerero, C.; Reche, C.; Massagué, J.; Via, M.; Minguillón, M.C.; Alastuey, A.; Querol, X. Changes in air quality during the lockdown in Barcelona (Spain) one month into the SARS-CoV-2 epidemic. Sci. Total Environ. 2020, 726, 138540. [CrossRef] [PubMed]

24. Javed, Z.; Liu, C.; Khokhar, M.F.; Tan, W.; Liu, H.; Xing, C.; Ji, X.; Tanvir, A.; Hong, Q.; Sandhu, O.; et al. Ground-based MAX-DOAS observations of $\mathrm{CHOCHO}$ and $\mathrm{HCHO}$ in Beijing and Baoding, China. Remote Sens. 2019, 11, 1524. [CrossRef]

25. Danckaert, T.; Fayt, C.; Van Roozendael, M.; DeSmedt, I.; Letocart, V.; Merlaud, A.; Pinardi, G. QDOAS Software User Manual; Belgian Institute for Space Aeronomy: Brussels, Belgium, 2017.

26. Chance, K.; Kurucz, R. An improved high-resolution solar reference spectrum for Earth's atmosphere measurements in the ultraviolet, visible, and near infrared. J. Quant. Spectrosc. Radiat. Transf. 2010, 111, 1289-1295. [CrossRef]

27. Vandaele, A.C.; Hermans, C.; Simon, P.C.; Carleer, M.; Colin, R.; Fally, S.; Merienne, M.-F.; Jenouvrier, A.; Coquart, B. Measurements of the $\mathrm{NO}_{2}$ absorption cross-section from $42000 \mathrm{~cm}^{-1}$ to $10000 \mathrm{~cm}^{-1}(238-1000 \mathrm{~nm})$ at $220 \mathrm{~K}$ and 294 K. J. Quant. Spectrosc. Radiat. Transf. 1998, 59, 171-184. [CrossRef]

28. Meller, R.; Moortgat, G.K. Temperature dependence of the absorption cross sections of formaldehyde between 223 and $323 \mathrm{~K}$ in the wavelength range 225-375 nm. J. Geophys. Res. Space Phys. 2000, 105, 7089-7101. [CrossRef]

29. Serdyuchenko, A.; Gorshelev, V.; Weber, M.; Chehade, W.; Burrows, J.P. High spectral resolution ozone absorption cross-sections-Part 2: Temperature dependence. Atmos. Meas. Tech. 2014, 7, 625-636. [CrossRef]

30. Fleischmann, O.C.; Hartmann, M.; Burrows, J.P.; Orphal, J. New ultraviolet absorption cross-sections of BrO at atmospheric temperatures measured by time-windowing Fourier transform spectroscopy. J. Photochem. Photobiol. A Chem. 2004, 168, 117-132. [CrossRef]

31. Thalman, R.; Volkamer, R. Temperature dependent absorption cross-sections of $\mathrm{O}_{2}-\mathrm{O}_{2}$ collision pairs between 340 and $630 \mathrm{~nm}$ and at atmospherically relevant pressure. Phys. Chem. Chem. Phys. 2013, 15, 15371-15381. [CrossRef] [PubMed]

32. Solomon, S.; Schmeltekopf, A.L.; Sanders, R.W. On the interpretation of zenith sky absorption measurements. J. Geophys. Res. Space Phys. 1987, 92, 8311-8319. [CrossRef]

33. Wagner, T.; Ibrahim, O.; Shaiganfar, R.; Platt, U. Mobile MAX-DOAS observations of tropospheric trace gases. Atmos. Meas. Tech. 2010, 3, 129-140. [CrossRef]

34. Celarier, E.A.; Brinksma, E.J.; Gleason, J.F.; Veefkind, J.P.; Cede, A.; Herman, J.R.; Ionov, D.; Goutail, F.; Pommereau, J.-P.; Lambert, J.-C.; et al. Validation of Ozone Monitoring Instrument nitrogen dioxide columns. J. Geophys. Res. Space Phys. 2008, 113. [CrossRef]

35. Javed, Z.; Liu, C.; Khokhar, M.F.; Xing, C.; Tan, W.; Subhani, M.A.; Rehman, A.; Tanvir, A. Investigating the impact of Glyoxal retrieval from MAX-DOAS observations during haze and non-haze conditions in Beijing. J. Environ. Sci. 2019, 80, 296-305. [CrossRef] [PubMed]

36. Gratsea, M.; Vrekoussis, M.; Richter, A.; Wittrock, F.; Schönhardt, A.; Burrows, J.; Kazadzis, S.; Mihalopoulos, N.; Gerasopoulos, E. Slant column MAX-DOAS measurements of nitrogen dioxide, formaldehyde, glyoxal and oxygen dimer in the urban environment of Athens. Atmos. Environ. 2016, 135, 118-131. [CrossRef]

37. Hendrick, F.; Müller, J.-F.; Clémer, K.; De Mazière, M.; Fayt, C.; Hermans, C.; Stavrakou, T.; Vlemmix, T.; Wang, P.; Van Roozendael, M. Four years of ground-based MAX-DOAS observations of $\mathrm{HONO}$ and $\mathrm{NO}_{2}$ in the Beijing area. Atmos. Chem. Phys. Discuss. 2014, 14, 765-781. [CrossRef]

38. Tian, X.; Xie, P.; Xu, J.; Li, A.; Wang, Y.; Qin, M.; Hu, Z. Long-term observations of tropospheric $\mathrm{NO}_{2}, \mathrm{SO}_{2}$ and HCHO by MAX-DOAS in Yangtze River Delta area, China. J. Environ. Sci. 2018, 71, 207-221. [CrossRef]

39. Stockwell, W.R.; Forkel, R. Ozone and volatile organic compounds: Isoprene, terpenes, aldehydes, and organic acids. In Trace Gas Exchange in Forest Ecosystems; Springer Science and Business Media LLC: Berlin, Germany, 2002; pp. 257-276.

40. Sillman, $\mathrm{S}$. The use of $\mathrm{NOy}, \mathrm{H}_{2} \mathrm{O}_{2}$, and $\mathrm{HNO}_{3}$ as indicators for ozone-NOx-hydrocarbon sensitivity in urban locations. J. Geophys. Res. Space Phys. 1995, 100, 14175-14188. [CrossRef] 
41. Duncan, B.N.; Yoshida, Y.; Sillman, S.; Retscher, C.; Pickering, K.E.; Martin, R.V.; Celarier, E.A. The sensitivity of US surface ozone formation to NOx, and VOCs as viewed from space. In Proceedings of the 8th Annual CMAS Conference, Chapel Hill, NC, USA, 19-21 October 2009.

42. Javed, Z.; Liu, C.; Ullah, K.; Tan, W.; Xing, C.; Liu, H. Investigating the effect of different meteorological conditions on MAX-DOAS observations of $\mathrm{NO}_{2}$ and $\mathrm{CHOCHO}$ in Hefei, China. Atmosphere 2019, 10, 353. [CrossRef]

43. Chan, K.L.; Wang, Z.; Ding, A.; Heue, K.-P.; Shen, Y.; Wang, J.; Zhang, F.; Shi, Y.; Hao, N.; Wenig, M. MAX-DOAS measurements of tropospheric $\mathrm{NO}_{2}$ and $\mathrm{HCHO}$ in Nanjing and a comparison to ozone monitoring instrument observations. Atmos. Chem. Phys. Discuss. 2019, 19, 10051-10071. [CrossRef]

Publisher's Note: MDPI stays neutral with regard to jurisdictional claims in published maps and institutional affiliations.

(C) 2020 by the authors. Licensee MDPI, Basel, Switzerland. This article is an open access article distributed under the terms and conditions of the Creative Commons Attribution (CC BY) license (http://creativecommons.org/licenses/by/4.0/). 